culties due to the high social station of the persons to be studied. I readily agree that the discussion of opposing views can only further our knowledge in every field. But we must avoid that discussion becomes dispute.-I am, etc.,

\section{A. Gajdos,}

Head of Biochemical Research Laboratory, Medical Clinic,

Hôtel Dieu Hospital, Hốtel Dieu.

Paris.

\section{Mastectomy Stand}

SIR,-Patients undergoing radical mastectomy present a problem to the theatre personnel in the application of bandages to the area involved. This usually entails staff holding the patients in a semi-upright position while the bandage is applied. The stand illustrated is of considerable value in reducing the number of staff involved in this procedure. The back and head support are of solid Formica and are extendable. The base and metal parts are made of polished stainless steel.

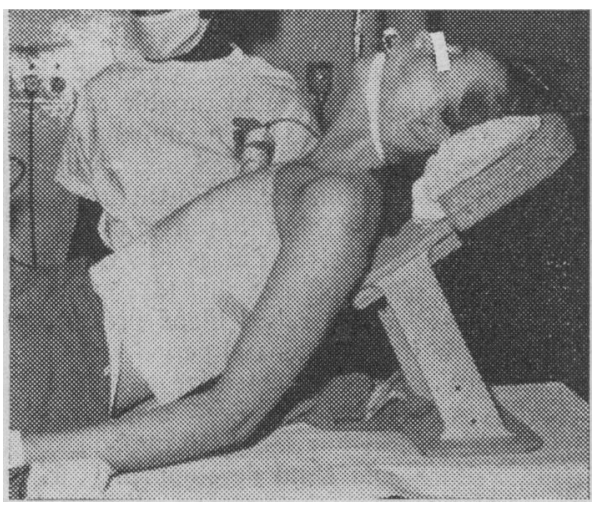

The stand is placed under the patient's back with a special rest for the head. This head-rest can be extended if required. The bandage is applied in the usual manner and encompasses the stand. When the bandaging is completed the stand is removed head first.' If, owing to the postoperative condition, it is preferable to have the patient lying flat rather than upright then this can be achieved by tilting the table into the Trendelenburg position. This allows the patient to lie flat.

The apparatus can be obtained from $A$. $\mathbf{L}$. Hawkins and Company, Surgical Instrument Makers, 15 Cavendish Street, London W., and the cost is approximately $£ 35$.-We are, etc.,

G. R. Clarke.

E. Thomas

G. L. Proctor.

East Birmingham Hospital.

Birmingham 9.

\section{Haemostatic Factor in Peanuts}

SIR,-There is need for a double-blind test for a definitive demonstration of the presence or absence of a haemostatic factor in peanuts, but we wish to emphasize certain inadequacies of the double-blind test reported by Verstraete and Ruys ${ }^{1}$ in which they found negative results. This is to avoid any possible impression that the issue is settled. Their test was based upon the assumption that their peanut extract would delay fibrinolysis, but their test subjects were severe bleeders in whom one would expect to find very little haemostatically important fibrin. The delay of fibrinolysis might be expected to be more effective in milder bleeders. Secondly, if our interpretation of their description of preparation of this material is correct it would appear that a possibly important haemostatic substance was eliminated from their preparation. Choline compounds were not detectable in the material. Choline-containing material have been isolated from peanut extracts, and seem to have a haemostatic action." Thirdly, by comparison with the quantities used in our studies, ${ }^{4}$ the amounts used by them were small by a factor of eightfold to tenfold. Even if the preparation had retained choline-containing substances, the tests probably would have been negative.

Our main point in this communication is to emphasize that further research in this field is required, and the need for doubleblind tests with other materials remains.We are, etc.,

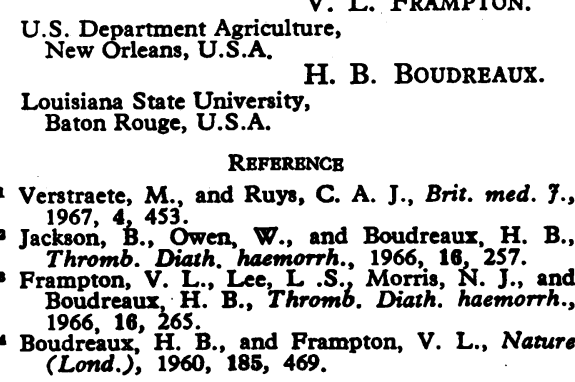

\section{REFERENCB}

\section{Faradic Stimulation for Incontinence}

SIR,-Encouraged by the results of Moore and Schofield, ${ }^{1}$ we have treated 15 patients suffering from incontinence of urine of varying causes by faradic stimulation. The anaesthetized patients were placed in the lithotomy position and were given 10 faradic stimulations using a triodyne electrical treatment unit (Mottershead and Company). The faradic stimulus consisted of surged impulses, each of 1.2 milliseconds' duration, the whole surge lasting for two to three seconds and being repeated after a further three seconds. The indifferent electrode was placed over the sacrum and the active electrode over the perineum. Both were covered in gauze and moistened with tap-water. Though the intensity of stimulus received by each patient varied, it was in each case sufficient to cause contraction of the muscles of the pelvic floor and buttocks.

The causes of the incontinence, and the results of the treatment, are shown in the Table. Every patient in whom improvement occurred has been followed for three months or more.

Only one of our patients was cured, though eight of the remainder improved. Of these, seven had true stress incontinence. The failure of this treatment in three of the four patients with neurological disease and two of the four with incontinence of urine after prostatectomy is of course not surprising. Any assessment of the value of the procedure

\begin{tabular}{|c|c|c|}
\hline Cause & $\begin{array}{l}\text { Duration } \\
\text { of Incontinence }\end{array}$ & $\begin{array}{l}\text { Result } \\
\text { of Treatment }\end{array}$ \\
\hline $\begin{array}{l}\text { Multiple } \\
\text { sclerosis } \\
\text { Multiple } \\
\text { sclerosis } \\
\text { Cerebellar } \\
\text { degeneration } \\
\text { Tabes dorsalis }\end{array}$ & $\begin{array}{l}15 \text { years } \\
20 \text { years } \\
6 \text { months } \\
2 \text { years }\end{array}$ & $\begin{array}{l}\text { No change } \\
\text { No change } \\
\text { No change } \\
\text { Continent by day }\end{array}$ \\
\hline Senility & $\begin{array}{l}1 \text { year. } \\
\text { Remained incon- } \\
\text { tinent after } \\
\text { transurethral } \\
\text { prostactectomy }\end{array}$ & Continent by day \\
\hline $\begin{array}{l}\text { Transurethral } \\
\text { prostactectomy } \\
\text { Transurethral }\end{array}$ & $\begin{array}{l}4 \text { months post- } \\
\text { operatively } \\
7 \text { years post- }\end{array}$ & $\begin{array}{l}\text { Continent by day } \\
\text { and by night } \\
\text { No change }\end{array}$ \\
\hline $\begin{array}{l}\text { prostactectomy } \\
\text { Retropubic }\end{array}$ & $\begin{array}{l}\text { operatively } \\
4 \text { years post- }\end{array}$ & No change \\
\hline $\begin{array}{l}\text { Stress } \\
\text { incontinence }\end{array}$ & 19 years & $\begin{array}{l}\text { Improved, still } \\
\text { occasionally wet }\end{array}$ \\
\hline $\begin{array}{l}\text { Stress } \\
\text { incontinence }\end{array}$ & 11 years & $\begin{array}{l}\text { Improved, still } \\
\text { occasionally wet }\end{array}$ \\
\hline $\begin{array}{l}\text { Stress } \\
\text { incontinence }\end{array}$ & 8-9 years & $\begin{array}{l}\text { Improved, still } \\
\text { occasionally wet }\end{array}$ \\
\hline $\begin{array}{l}\text { Stress } \\
\text { incontinence }\end{array}$ & 3 years & $\begin{array}{l}\text { Improved, still } \\
\text { occasionally wet }\end{array}$ \\
\hline $\begin{array}{l}\text { Stress } \\
\text { incontinence }\end{array}$ & 18 months & $\begin{array}{l}\text { Improved, still } \\
\text { occasionally wet }\end{array}$ \\
\hline $\begin{array}{l}\text { Stress } \\
\text { incontinence }\end{array}$ & 6 months & $\begin{array}{l}\text { Improved, still } \\
\text { occasionally wet }\end{array}$ \\
\hline $\begin{array}{l}\text { Stress } \\
\text { incontinence }\end{array}$ & 3 years & No change \\
\hline
\end{tabular}
as a therapeutic measure depends on the maintenance of continence after an interval, and it will be noted ti:at only one of the nine patients who benefited remained dry by day and by night up to three months after treatment.

Our results are inferior to those of Moore and Schofield and suggest that a single treatment with faradic stimulation to the perineum under general anaesthesia is unlikely to cure

these patients. It may, however, be of diagnostic value in distinguishing those patient who might be improved by some form of operative treatment for stress incontinence and is certainly a help for some elderly patients in whom operation might be inadvisable.-We are, etc.

\section{St James's Hospital, PhLIP H. SMITH.}

Leeds.

\section{Rapropace} Moore, T., and Schofield, P. F., Brit. med. Y.,

\section{Sales Promotion}

SIR,-May I respectfully suggest that Dr. O. W. Samuel (4 May, p. 303) has no need " to voluntarily submit to a torrent of un-" wanted commercial advertising"?

He should write to the Secretary, Association of British Pharmaceutical Industries, 162 Regent Street, London $W .1$, requesting that his name be removed from the mailing lists of member companies. This should ensure $90 \%$ reduction of advertising material with out affecting his supplies of the other worthy publications to which he refers in his letter. -I am, etc.,

A. YEADON,
$\begin{gathered}\text { Medical Adviser, } \\ \text { Queenborough, } \\ \text { Kent }\end{gathered}$
Abbott Laboratories Ltd.

SIR,-Dr. O. W. Samuel (4 May, p. 303) requested deletion from all mailing lists, and, as he was kind enough to say, his request was immediately honoured. This is why he has not received Prop List, Prescribers' fournal, etc., or any advertising literature. It is almost impossible for any company to meet every request from the profession. They are so varied. We think, however, that 